\title{
Reproduction and structure of the population of the Chaetognath Parasagitta friderici in Guanabara Bay (Brazil) based on short term sampling
}

\author{
FABIANA MENDES, GISELA M. DE FIGUEIREDO and JEAN L.VALENTIN \\ Laboratório de Zooplâncton Marinho, Departamento de Biologia Marinha, Instituto de Biologia, \\ Universidade Federal do Rio de Janeiro (UFRJ), Rua Professor Rodolpho Paulo Rocco, 211, Prédio do CCS, \\ bloco A1, sala 079, Cidade Universitária, 21249-617 Rio de Janeiro, RJ, Brasil \\ Manuscript received on July 30, 2010; accepted for publication on January 31, 2011
}

\begin{abstract}
The aim of this study was to describe the total density, densities of developmental stages and the reproduction period of Parasagitta friderici. Weekly samples were collected at one station in the channel of Guanabara Bay, Rio de Janeiro, during one year. Three vertical hauls were made for each sample, and $P$. friderici was separated, the developmental stages were identified, and body length (BL), ovary length (OL) and seminal vesicle width (SVW) were measured. Throughout the year $P$. friderici was the most abundant chaetognath species occurring in all four developmental stages, the densities of which varied from week to week. Higher densities of adults occurred in the spring, followed by peaks of juveniles in the summer. Although $P$. friderici seems to reproduce continuously in Guanabara Bay, a reproductive peak was apparent during the spring. The intensification of reproduction during the spring, with juveniles occurring in the summer, seems to be related to the period of higher food supply during the rainy season and intrusions of the South Atlantic Central Water.
\end{abstract}

Key words: Chaetognath, development stage, Guanabara Bay, reproduction.

\section{INTRODUCTION}

Chaetognaths are an important planktonic group that occurr from polar to tropical waters and often present in high densities in the zooplankton (Feigenbaum and Maris 1984). These organisms are hermaphroditic and carnivorous, feeding on zooplankton and fish larvae, but mainly on copepods (Reeve 1970, Feigenbaum 1991, Brodeur and Terazaki 1999). Several chaetognath

Correspondence to: Fabiana Mendes

E-mail: fabianamendes@ufrj.br species have proved to be important indicators of water masses (Casanova 1999).

In general, studies of chaetognaths or other mesozooplankton groups tend to collect data from few samples and short periods, with long sampling intervals (Batistic et al. 2007). These sampling methods may overlook important information about oscillations in plankton densities (Reeve 1970). Finer-scale sampling is especially important in understanding the temporal distributions of certain zooplankton species, some of which have life cycles measured only in days (Batistic et al. 2007). Relatively few studies sample on short 
time scales, i.e., hours, days and weeks, which are more concurrent with regional oceanographic and ecological processes (Lopes 2007) and also with zooplankton life cycles. In Guanabara Bay in the state of Rio de Janeiro, seasonal events cause thermal and salinity stratification of the water column, which may cause rapid alterations in plankton populations (Valentin et al. 1999a). The greatest changes in the hydrobiological conditions of Guanabara Bay are influenced by the entrance of a cold coastal water mass (South Atlantic Central Waters, SACW) into the Bay and the increase of precipitation during the austral spring-summer period (Mayr et al. 1989, Kjerfve et al. 1997).

In Brazil, chaetognath studies have dealt mainly with distribution (Almeida Prado 1961a, Fernandes et al. 2005) or population structure and feeding (Nair and Sankarankutty 1988, Vega-Pérez and Liang 1992, Liang and Vega-Pérez 1994, 1995, 2002). In Guanabara Bay, three species of chaetognaths are abundant; Parasagitta friderici Ritter-Zàhony is the dominant species, followed by Flaccisagitta enflata Grassi and Ferosagitta hispida Conant (Marazzo and Nogueira 1996). Parasagitta friderici is widely distributed worldwide, occurring in the Pacific, Mediterranean and Atlantic, as well as in Brazilian estuaries and coasts (Almeida Prado 1961b, Fernandes et al. 2005, Avila et al. 2006). In Guanabara Bay, the few studies on this species have examined its distribution (Marazzo and Nogueira 1996), feeding (Marazzo et al. 1997) and vertical migration (Castellões 2000). However, there is little information about the life cycle, reproduction, and importance of this species in the pelagic food web (e.g., Gibbons 1994, Daponte et al. 2004). The aim of this study was to describe the density, reproduction period and structure of the P. friderici population in terms of developmental stages. We collected samples in short (weekly) time intervals to minimize possible bias related to the short life cycle of this species.

\section{MATERIALS AND METHODS}

Weekly samples were collected at one station ( $20 \mathrm{~m}$ depth) located in the main channel of Guanabara Bay, Rio de Janeiro, Brazil (2254'04” S and $43^{\circ} 08^{\prime} 53$ ' W) during one year (September 2003 through August 2004). Three vertical hauls were conducted using a conical net of $60 \mathrm{~cm}$ diameter and $200 \mu \mathrm{m}$ mesh size, with a calibrated flowmeter attached. Samples were fixed in $4 \%$ formalin buffered with sodium tetraborate. Data for temperature and salinity at the surface and near the bottom were obtained using a thermosalinometer (Labcomp SCTPH). Precipitation data were obtained from the Instituto Nacional de Meteorologia (INMET).

Chaetognaths were separated from the samples and identified to species level. For the dominant species Parasagitta friderici, the developmental stages of at least 100 individuals were identified in each sample. The stages were separated based on the classification proposed by Kehayias et al. (1999), in which: stage I - young without visible ovaries; stage II - visible ovaries but not seminal vesicles; stage III - both ovaries and seminal vesicles visible; and stage IV- seminal vesicles filled with sperm, large ova in ovaries. Body length (BL), ovary length (OL), and seminal vesicle width (SVW) were measured using a microscope with a camera attached and an image analysis system (AxioVision ${ }^{\circledR}$ V.4.5, Carl Zeiss). The proportion between the ovary and body lengths was determined for each stage of development and season, according to Furnestin (1957).

Correlation tests were conducted between P. friderici densities and the abiotic factors such as temperature, salinity, tide and precipitation. Body length and gonads sizes were compared between developmental stages in each season of the year and between seasons using one-way Analysis of Variance (ANOVA) and Tukey posteriori test. The homogeneity of the variation was previously tested, but even if this assumption was not satisfied, the results were accepted when they showed a high 


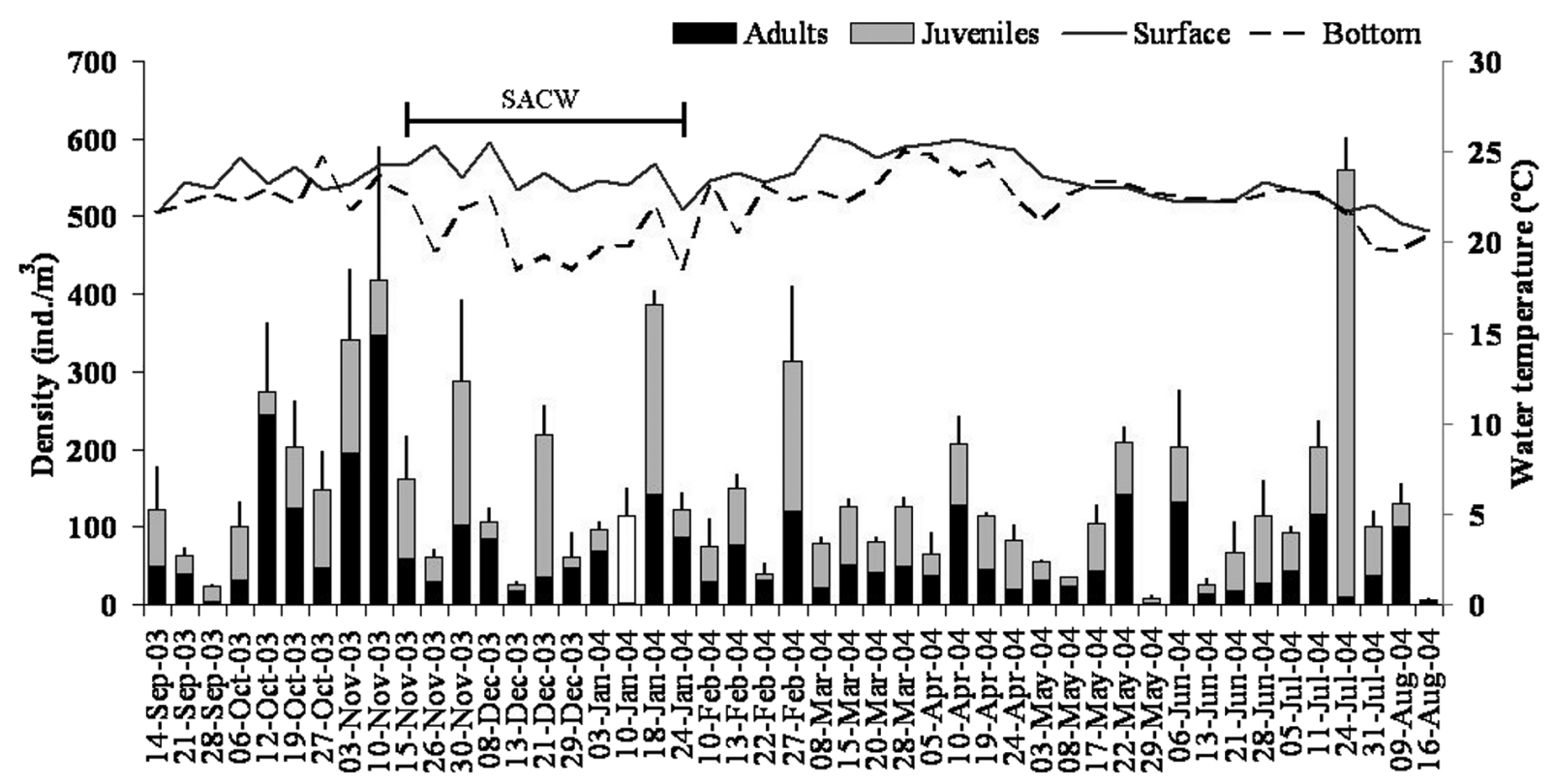

Fig. 1 - Means of density (+ standard errors) and contribution of the maturation stage of Parasagitta friderici in Guanabara Bay collected weekly over one year. Juveniles included stages I and II, and adults included stages III and IV. The development stages of the sample collected on January 10 was not identified (white bar). Lines indicate the variation of the mean of water temperature at the surface and at the bottom of water column (right y-axis).

level of significance $(p<0.01)$. Data higher or lower than 1.5 times the interquartile range were considered outliers and were omitted from the analysis. Statistical analyses were conducted using the software Statistica version 7 (Statsoft 2004).

\section{RESULTS}

Periods of thermal stratification in the water column occurred from November 2003 to January 2004 , caused by intrusion of cold water from the South Atlantic Central Water (SACW). During this period, surface water temperatures were between $22-26^{\circ} \mathrm{C}$ and the bottom temperature was $\sim 18^{\circ} \mathrm{C}$ (Fig. 1). Water stratification due to low salinity $(<30)$ at the surface occurred at irregular intervals from October to March, caused by high rainfall in the region during the spring and summer.

Three species of chaetognaths were found in Guanabara Bay. Parasagitta friderici comprised $95 \%$ of the total individuals collected, followed by Flaccisagitta enflata (4\%) and Ferosagitta hispida (1\%). In general, in each sample, P. friderici contributed $\sim 90 \%$ to total chaetognath density, except at the end of June and beginning of July (70-80\%). Densities of $P$. friderici varied weekly and showed no clear pattern over the year (Fig.1). The highest density was $560 \mathrm{ind} . / \mathrm{m}^{3}$ on July 24 , and the lowest was 6.5 ind. $/ \mathrm{m}^{3}$ on August 16 (Fig. 1). Higher densities occurred from the end of October to the beginning of November, just prior to the intrusion of the SACW. However, there were no significant correlations $(p>0.05)$ between weekly density variations of $P$. friderici and the abiotic factors (temperature, salinity, tide, and precipitation). Juveniles (stages I and II) and adults (stages III and IV) occurred throughout the year, although their relative contributions also varied widely week to week (Fig. 1). The highest density of adults was observed at the end of the spring (October-November), and it was followed by sporadic peaks of juveniles. 

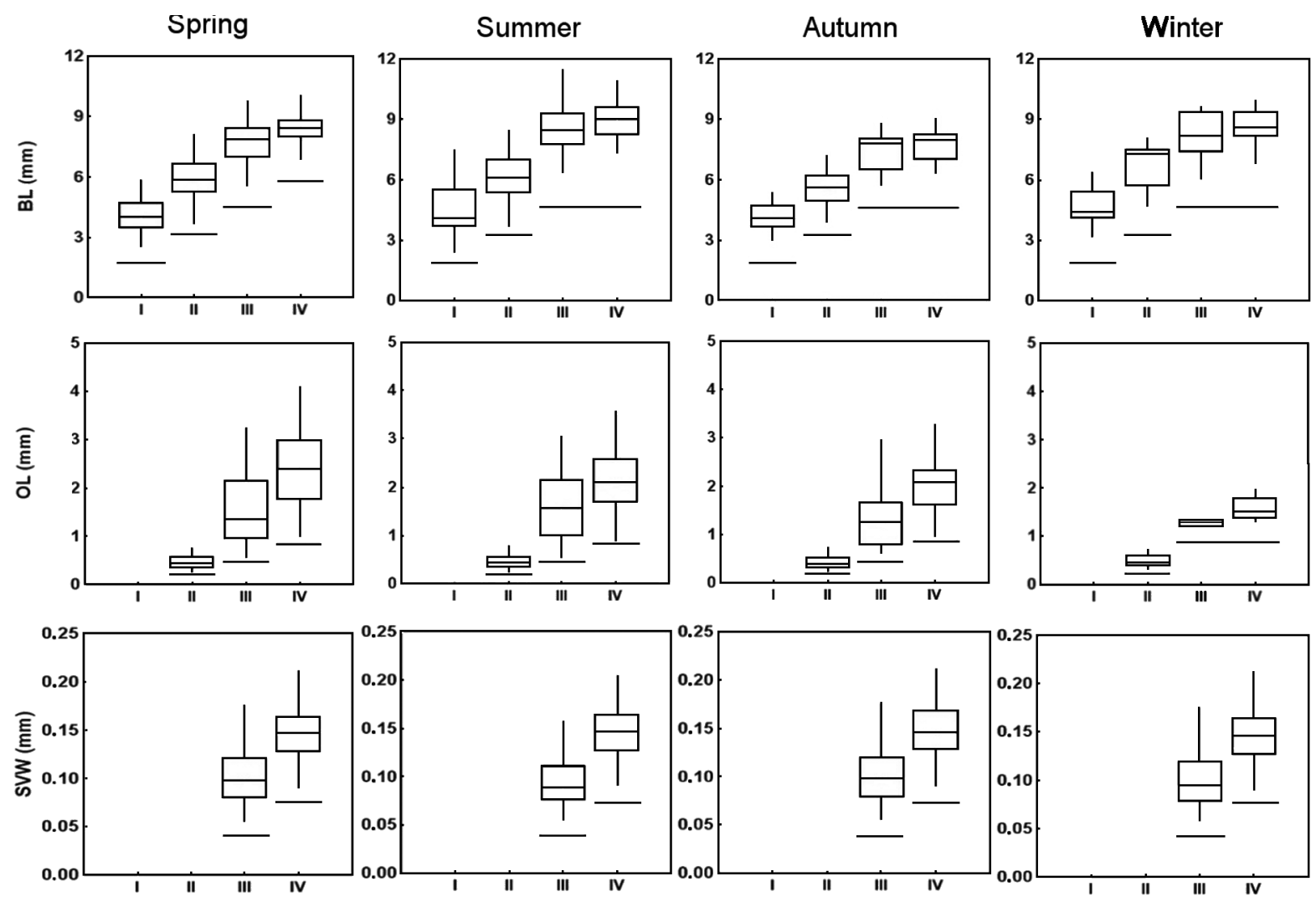

Fig. 2 - Changes in the body length (BL), ovary length (OL) and seminal vesicle width (SVW) during the ontogenetic development (stages I-IV) in each season of the year (summer, spring, autumn and winter). The box represents the median value (horizontal segment), the range containing $50 \%$ of the individuals (box), and vertical segments represent 1.5 times the interquartile range. The horizontal line below each box indicates that there were significantly differences (one-way ANOVA, $\mathrm{p} \leq 0.05$ ), and the horizontal line below two boxes indicates that there were no significant differences (one-way ANOVA, $\mathrm{p} \geq 0.05$ ).

A total of 650 individuals of $P$. friderici were measured for comparisons of body length (BL), ovary length (OL), and seminal vesicle width (SVW) between the stages of development in each season. ANOVA comparisons of BL between stages for each season showed significant results (spring $F_{(3,245)}$ $=312.6, \mathrm{p}<0.00001 ;$ summer $\mathrm{F}_{(3,210)}=151.2, \mathrm{p}<$ 0.00001 ; autumn $\mathrm{F}_{(3,106)}=105.4, \mathrm{p}<0.00001$; winter $\left.\mathrm{F}_{(3,63)}=41.3, \mathrm{p}<0.00001\right)$ (Fig.2). The BL increased with development until stage III (Tukey test, $\mathrm{p}<0.05)$ and there was no increase in body length from stages III to IV (Tukey test, $p>0.05$ ), except during the spring when body length differed among all development stages (Tukey test, $\mathrm{p}<0.05$ ) (Fig. 2). The range of body length of $P$. friderici was 2.5-12 $\mathrm{mm}$, and individuals longer than $10 \mathrm{~mm}$ occurred only during spring and summer. Comparisons of BL at each stage between seasons showed differences for stage II, where individuals collected during the autumn were larger than during the winter $\left(\mathrm{F}_{(3,158)}=3.8\right.$, $\mathrm{p}<0.05$; Tukey, $\mathrm{p}<0.05)$. Seasonal differences in body length also occurred for stages III $\left(\mathrm{F}_{(3,146)}=7.4\right.$, $\mathrm{p}<0.05)$ and $\operatorname{IV}\left(\mathrm{F}_{(3,181)}=13.6, \mathrm{p}<0.05\right)$. For both stages, individuals collected in the summer were larger $(p<0.05)$, and individuals collected in the autumn were smaller $(\mathrm{p}<0.05)$. Thus, adults reach their maximum size at stage III, except in spring when they grow larger from stage III to IV. However, during the summer the maximum size is reached earlier (stage III) and is larger than in the other season.

Comparisons of ovary length (OL) also showed significant differences between the stages 
for all seasons (i.e., spring $\mathrm{F}_{(2,161)}=127.8, \mathrm{p}<0.0001$; summer $\mathrm{F}_{(2,123)}=151.1, \mathrm{p}<0.00001$; autumn $\mathrm{F}_{(2,63)}=71.9, \mathrm{p}<0.00001$; winter $\mathrm{F}_{(2,25)}=42.1$, $\mathrm{p}<0.00001$ ), and the ovaries increased according to the developmental stage (Tukey test, $\mathrm{p}<0.05$ ). The exception occurred for samples collected during the winter, when there were no significant differences between ovary length of individuals in stages III and IV (Tukey test, $p>0.05$ ) (Fig. 2). There were no seasonal differences in OL for individuals in stages II and III $(p>0.05)$. For individuals in stage IV, significant differences were found $\left(\mathrm{F}_{(3,118)}=3.4\right.$; $\mathrm{p}<0.05)$. Although the Tukey test did not confirm differences in ovary length between seasons, a visual pattern shows an increase of ovary size (winter $<$ autumn $<$ summer $<$ spring) (see Fig. 2).

Seminal vesicle width (SVW) was significantly larger in stage IV for all seasons (one-way ANOVA: spring $\mathrm{F}_{(1,45)}=114, \mathrm{p}<0.00001$; summer $\mathrm{F}_{(1,85)}=43, \mathrm{p}<0.00001$; autumn $\mathrm{F}_{(1,64)}=67$, $\mathrm{p}<0.00001$; winter $\left.\mathrm{F}_{(1,32)}=44.7, \mathrm{p}<0.00001\right)$ (Fig. 2). Seasonal comparisons showed that individuals in stage III collected in the summer had wider seminal vesicles than those collected in the spring and autumn $\left(\mathrm{F}_{(3,144)}=5.4, \mathrm{p}<0.05\right.$; Tukey test, $\mathrm{p}<0.05)$, whereas for individuals in stage IV there were no significant differences.

The proportion between ovary and body length of $P$. friderici in stage IV showed that during the spring, $42 \%$ of individuals had ovaries corresponding to 30 to $45 \%$ of body length, while during the summer only $18 \%$ of individuals had ovaries corresponding to 30 to $40 \%$ of body length. In contrast, during the winter, $80 \%$ of individuals had ovaries corresponding to 8 to $16 \%$ of body length. At stage III, $41 \%$ of individuals in the spring, $37 \%$ in the summer, and $33 \%$ in autumn had ovaries occupying 20 to $30 \%$ of their body length. Thus, the highest percentage of individuals of $P$. friderici with ovaries occupying a higher part of their body, in both stages III and $\mathrm{IV}$, occurred in the spring.

\section{DISCUSSION}

\section{PARASAGITTA FRIDERICI DENSITY OVER THE YEAR}

In Guanabara Bay, P. friderici has been very abundant since it was first recorded (Costa 1970). In the current study, it was the most abundant chaetognath species throughout the year. Parasagitta friderici is often reported in estuaries on the south coast of Brazil, and also in Uruguay and Argentina. In the latter, it was the only species that occurred in areas strongly influenced by fresh water in the La Plata River (Boltovskoy 1975). In the present study, higher densities of $P$. friderici occurred in spring and summer, particularly during the rainy season (October through March) and sporadic intrusions of the SACW (November through January). High densities of zooplankton, which were previously reported in Guanabara Bay from January to May, were attributed to the influence of the summer rains (Nogueira et al. 1988) and the influx of coastal waters (Marazzo and Nogueira 1996). Both factors increase nutrient levels in the Bay, which increases phytoplankton production and subsequent zooplankton densities. Early studies showed that the density of prey, mainly copepods, may be a key factor influencing the spatial and temporal distribution of chaetognath density (Marazzo and Nogueira 1996, Hernandez et al. 2005, Tse et al. 2007). Thus, the higher densities of $P$. friderici in Guanabara Bay during the spring and summer seem to be related to high food availability. Further studies should consider simultaneous sampling of $P$. friderici and their prey on fine scales.

Density of $P$. friderici showed oscillations from week to week as it was demonstrated for other zooplankton taxa collected in short intervals of time (Józefczuk et al. 2003). The weekly variation in $P$. friderici density was not related with the abiotic factors tested, i.e. temperature, salinity, tide and precipitation. These factors do not seem to influence $P$. friderici densities in Guanabara Bay possible due to its high tolerance to the temperature 
and salinity variations (Bieri 1959, Almeida Prado 1961b, Marazzo and Nogueira 1996, Fernandes et al. 2005). Abiotic factors and population dynamics determine the variations in zooplankton density, and, to better distinguish these oscillations, short sampling intervals, i.e. weekly or hourly, are recommended (Batistic et al. 2007, Lopes 2007). Other factors not approached here, such as population dynamics and currents that carry $P$. friderici into the Bay, could have influenced the chaetognath densities. Although we did not recognize the causes of the short-term variation of $P$. friderici densities, our results clearly indicated the wide variability in $P$. friderici densities within a month. Therefore, we suggest that studies of population dynamics of chaetognaths consider short sampling intervals (i.e. week or days), particularly in dynamic environments such as estuaries and bays.

\section{Morphology of DeVelopmental Stages}

Several schemes have been proposed for the classification of the developmental stages of chaetognaths (see Boltovskoy 1981, Alvariño 1990). Here, we used the key proposed by Kehayias et al. (1999), particularly because it is simpler, there is no need to stain the specimens, it includes fewer stages of development, and it has been used for many species, making comparisons possible. Although this classification key does not include $P$. friderici, its application showed similarities with other keys proposed for this species (i.e., Alvariño 1969 apud Alvariño 1990, Daponte et al. 2004).

The classification of Kehayias et al. (1999) allowed us to clearly separate $P$. friderici into four stages. However, we observed some overlapping between sizes of individuals in different stages. For instance, individuals in stages III and IV did not show differences in body and ovary lengths. The overlapping in gonad size or body length for individuals of different stages has been ascribed to several causes, such as: limitations inherent to the classification keys (Daponte et al. 2004), variations in the timing between the development of male and female gonads (protandry) (Pearre 1991, Kehayias et al. 1999), contraction of the ovary after spawning (Pearre 1991), seasonal variation, and the constant mixture of individuals coming from different environmental conditions (e.g., food availability and temperature). Below, we discuss some reasons for the variability of gonads and body sizes within the developmental stages.

The overlapping between ovary lengths of individuals in stages III and IV occurred only in the winter, when individuals had smaller ovaries despite being mature. This suggests that during the winter there was less investment in reproduction. We also found the overlapping of body length between individuals in stages III and IV, except in the spring. In general, $P$. friderici in Guanabara Bay reaches its maximum size at stage III, and thereafter the energetic investment is directed to the development of gonads instead of the somatic body. During the summer, the maximum size, which is the largest of the year, is also reached earlier, in stage III. On the other hand, during the spring, $P$. friderici seems to be able to invest in both reproduction and somatic growth. In our study, the overlapping in sizes between individuals at different stages of development seems to be related to environmental conditions, particularly to the seasonal variations in Guanabara Bay. Body and gonad sizes not only showed overlapping, but also differed among individuals in the same stage of development that were collected in different seasons. Therefore, given the high variability of gonads size within a stage, the use of classification keys for developmental stages that employ body morphology instead of considering proportions based on gonad sizes is advisable.

REPRODUCTION OF PARASAGITTA FRIDERICI

All four developmental stages of $P$. friderici were collected throughout the year, indicating continuous reproduction in Guanabara Bay. Even sampling over short intervals, we found no clear reproductive 
pattern. However, a reproductive peak was recognized during the spring, when higher densities of adults occurred, followed by peaks of juveniles in the summer. To better identify periods when reproduction is more intense, we also analyzed the size of ovaries. Our results showed a higher frequency of individuals with ovaries corresponding to a larger part of body during the spring (twice the frequency found in the summer), which seems to indicate a higher reproductive activity.

Parasagitta friderici may reproduce continuously through the year since the temperature does not oscillate widely (range between $17-31^{\circ} \mathrm{C}$, Kjerfve et al. 1997) and the density of copepods remains high $\left(\sim 15.000\right.$ ind.$\left./ \mathrm{m}^{3}\right)$ (Valentin et al. 1999b). However, the intensification of reproduction during the spring seems to be related to the period of the rainy season and intrusions of the SACW into the Bay, increasing the food supply, i.e., copepods. The intrusion of SACW in Guanabara Bay is an important event in this ecosystem because it brings cold water with high nitrate and oxygen contents (Valentin et al. 1999b). During this period, the primary production increases in the Bay, which results in higher density and quality of food available to zooplankton. The association of higher densities of juveniles of $P$. friderici with the SACW was also reported for the São Paulo coast (Liang and Vega-Pérez 2002). In Guanabara Bay, densities of copepods tend to be high in the summer (Nogueira et al. 1988), when we also found higher densities of juveniles of $P$. friderici. Thus, the maturation of $P$. friderici in Guanabara Bay may be coupled with copepod reproduction, as demonstrated for F. enflata off the Chilean coast (Giesecke and González 2008). Similar patterns of continuous reproduction with peaks of intensification were observed for $P$. friderici during the spring and summer off the Iberian Peninsula (Alvariño 1990) and in the spring and autumn on the Argentina coast (Daponte et al. 2004). In the Cananéia estuary in São Paulo, the continuous reproduction with three reproductive peaks in one year was associated with the temperature and hydrology of the region (Liang et al. 2003).

In summary, the current study, conducted on a short temporal scale, showed wide oscillations in the structure (density and age) of $P$. friderici population. The pattern of continuous reproduction with a peak in the spring and juveniles in the summer was better demonstrated by coupling the analyses of densities of the developmental stages and the frequency of individuals with ovaries filling a larger part of the body. Finally, in Guanabara Bay the reproduction of $P$. friderici seems to benefit from the high food supply during the spring and summer.

\section{ACKNOWLEDGMENTS}

We are grateful to FJP Matos for helping with field sampling, and JA Castro for counting and measuring chaetognaths. We also thank three anonymous referees who provided comments to a former version of this article. Financial assistance was provided by Fundação Carlos Chagas Filho de Amparo à Pesquisa do Estado do Rio de Janeiro (FAPERJ) and Conselho Nacional de Desenvolvimento Científico e Tecnológico (CNPq). F Mendes was supported by a fellowship from FAPERJ.

\section{RESUMO}

O objetivo deste estudo foi descrever a densidade total, densidades dos estágios de desenvolvimento e o período reprodutivo de Parasagitta friderici. As coletas foram realizadas semanalmente durante um ano em uma estação no canal da Baía de Guanabara, Rio de Janeiro. Foram realizados três arrastos verticais em cada amostragem e, P. friderici foi separada, os estágios de desenvolvimento identificados e o comprimento do corpo, comprimento dos ovários e a largura da vesícula seminal foram medidos. Ao longo do ano, P. friderici foi a espécie de Chaetognatha mais abundante, ocorrendo em todos os quatro estágios de desenvolvimento, dos quais as 
densidades variaram entre as semanas. As densidades mais altas de adultos ocorreram na primavera seguidas de picos de juvenis no verão. Embora, $P$. friderici se reproduza continuamente na baía de Guanabara, um pico reprodutivo foi aparente durante a primavera. A intensificação da reprodução durante a primavera com a ocorrência de juvenis no verão, parece estar relacionada ao aumento da oferta de alimento durante a estação chuvosa e intrusões da Água Central do Atlântico Sul.

Palavras-chave: Chaetognatha, estágios de desenvolvimento, Baía de Guanabara, reprodução.

\section{REFERENCES}

AlmeIDA PRADO MS. 1961a. Chaetognatha encontrados em águas brasileiras. Bolm Inst Oceanogr S Paulo 11: 31-51.

AlmeIdA Prado MS. 1961b. Distribuição dos Chaetognatha no Atlântico Sul Ocidental. Bolm Inst Oceanogr S Paulo 11: $15-50$.

AlVARIÑO A. 1990. Chaetognatha. In: ADIYODI KG AND ADIYODI RG (Eds), Reproductive biology of invertebrates: Fertilization, development, and parental care, 4, New York: J Wiley \& Sons, p. 255-282.

AVILA LRM, ARRUDA MR AND BONECKER S. 2006 Chaetognatha. In: BONECKER SLC (Ed), Documentos REVIZEE Score Central: Atlas de Zooplâncton da região central da Zona Econômica Exclusiva brasileira, 21, Rio de Janeiro: Museu Nacional, p. 165-184.

BATISTIC M, JASPRICA N, CARIC M AND LUCIC D. 2007. Annual cycle of the gelatinous invertebrate zooplankton of the eastern South Adriatic coast (NE Mediterranean). J Plankton Res 29: 671-686.

BIERI R. 1959. The Distribution of the Planktonic Chaetognatha in the Pacific and their Relationship to the Water Masses. Limnol Oceanogr 4: 1-28.

BoltovsKoY D. 1975. Some Biometrical, Ecological, Morphological and Distributional Aspects of Chaetognata. Hydrobiologia 46: 515-534.

BolTOVSKOY D. 1981. Chaetognatha. In: BOLTOVSKOY D (Ed), Atlas del Zooplancton del Atlántico Sudoccidental y Métodos de Trabajo con el Zooplancton Marino, Mar del Plata, Argentina: Instituto Nacional de Investigación y desarrollo Pesquero, p. 759-785.

BRODEUR RD AND TERAZAKI M. 1999. Springtime abundance of chaetognaths in the shelf region of the northern Gulf of Alaska, with observations on the vertical distribution and feeding of Sagitta elegans. Fish Oceanogr 8: 93-103.
CASANOVA J-P. 1999. Chaetognatha. In: BOLTOVSKOY D (Ed), South Atlantic Zooplankton, 2, Leiden: Backhuys Publishers, p. 1353 -1374.

CASTELlÕES PV. 2000. Distribuição vertical do filo Chaetognatha em um ponto fixo na baía de Guanabara (RJ-Brasil), Rio de Janeiro: Museu Nacional - Universidade Federal do Rio de Janeiro, 130 p.

Costa P. 1970. Nota preliminar sobre ocorrência de Sagitta friderici e Sagitta enflata na Baia de Guanabara. Publ Inst Pesq Mar 47: 1-10.

Daponte MC, Capitanio FL, Nahabedian DE, Vinas MD AND NEGRI RM. 2004. Sagitta friderici RitterZahony (Chaetognatha) from South Atlantic waters: abundance, population structure, and life cycle. ICES J Mar Sci 61: 680-686.

FEIGENBAUM D. 1991. Food and feeding behaviour. In: BONE Q, KAPP H AND PIERROT-BULTS A (Eds), The biology of chaetognaths, Oxford: Oxford University Press, p. 45-54.

FEIGENBAUM D AND MARIS RC. 1984. Feeding in the Chaetognatha. Oceanogr Mar Biol Annu Rev 22: 343-392.

FERnANDES LL, SterzA JM AND NEVES KO. 2005. Seasonal Chaetognath abundance and distribution in a tropical estuary (Southeastern, Brazil). Braz j oceanogr 53: 47-53.

FURNESTIN M-L. 1957. Chaetognathes et zooplankton du secteur Atlantique Marocain. Rev Trav Inst Pech Marit 21: $1-356$

GiBbons MJ. 1994. Diel Vertical Migration and Feeding of Sagitta-Friderici and Sagitta-Tasmanica in the Southern Benguela Upwelling Region, with a Comment on the Structure of the Guild of Primary Carnivores. Mar Ecol-Prog Ser 111: 225-240.

GIESECKE R AND GonZÁlez HE. 2008. Reproduction and feeding of Sagitta enflata in the Humboldt Current system off Chile. ICES J Mar Sci 65: 361-370.

Hernandez RM, SuAREZ-Morales E AND Gasca R. 2005. Seasonal distribution of chaetognatha in a Mexican neotropical bay during a year cycle. J Coast Res 21: 186-192.

JózeFCZUK A, GuZERA E AND BIELECKA L. 2003. Short-term and seasonal variability of mesozooplankton at two coastal stations (Gdynia, Sopot) in the shallow water zone of the Gulf of Gdańsk. Oceanologia 45: 317-336.

Kehayias G, Koutsikopoulos C, Fragopoulu N AND LYKAKIS J. 1999. A single maturity classification key for five common Mediterranean chaetognath species. J Mar Biol Assoc Uk 79: 1137-1138.

KJERFVE B, RiBEIRO CHA, DiAs GTM, FILlipo AM AND VALÉRIA DSQ. 1997. Oceanographic characteristics of an impacted coastal bay: Baía de Guanabara, Rio de Janeiro, Brazil. Cont Shelf Res 17: 1609-1643. 
Liang TH, ARA K, Miranda LB, Bergamo AL AND BERNARDES M. 2003. On the variability of the chaetognath Sagitta friderici Ritter-Zahony at Cananéia Lagoon Estuarine system, São Paulo, Brazil. Hydrobiologia 510: 91-102.

LiAng TH AND VegA-PÉREZ LA. 1994. Studies on chaetognaths off Ubatuba region, Brazil, I. distribution and abundance. Bolm Inst Oceanogr S Paulo 42: 73-84.

Liang TH AND VegA-PÉrez LA. 1995. Studies on chaetognatha off Ubatuba region, Brazil. II. Feeding habits. Bolm Inst Oceanogr S Paulo 43: 27-40.

Liang TH AND VegA-PÉREZ LA. 2002. Distribution, abundance and biomass of Chaetognaths off São Sebatião region, Brazil in february 1994. Braz j oceanogr 50: 1-12.

LOPES RM. 2007. Marine zooplankton studies in Brazil A brief evaluation and perspectives. An Acad Bras Cienc 79: 369-379.

Marazzo A, Machado CF AND NogUeIRA CSR. 1997. Notes on feeding of Chaetognatha in Guanabara Bay, Brazil. J Plankton Res 19: 819-828.

MARAzZO A AND NoGUeIRA CSR. 1996. Composition, spatial and temporal variations of Chaetognatha in Guanabara Bay, Brazil. J Plankton Res 18: 2367-2376.

Mayr LM, Tenenbaun DR, Villac MC, Paranhos R, NOGUEIRA CR, BONECKER SL AND BONECKER AC. 1989. Hydrobiological Characterization of Guanabara Bay. In MAGOON OT AND NEVES C (Eds), Coastlines of Brazil, New York: American Society of Civil Engineering, p. 124-139.

NAIR VR AND SANKARANKUTTY C. 1988. Chaetognaths of Potengi Estuary (Natal, Northest Brazil). Atlântica 10: 5-20.
NogueIra CR, BoneCKer ACT AND BoneCKer SLC. 1988. Zooplâncton da Baía de Guanabara (RJ - Brasil) Composição e variações espaço-temporais, In: Encontro Brasileiro de Plâncton, 3, Caiobá, Brasil, p. 151-156.

PEARRE S JR. 1991. Growth and Reproduction. In: BONE Q, KAPP H and PIERROT-BULTS A (Eds), The biology of chaetognaths, Oxford: Oxford University Press, p. 61-75.

REEVE MR. 1970. The biology of Chaetognatha I. Quantitative aspects of growth and egg production in Sagitta hispida. In: STEELE JH (Ed), Marine Food Chains, Edinburgh: Oliver and Boyd, p. 168-189.

STATSOFT. 2004. STATISTICA: Data Analysis Software System. Version 7.0. Available from: www.statsoft.com.

TSE P, HUI SY AND WONG CK. 2007. Species composition and seasonal abundance of Chaetognatha in the subtropical coastal waters of Hong Kong. Estuar Coast Shelf Sci 73: $290-298$.

VAlentin JL, Tenenbaum D, Bonecker ACT, Bonecker $\mathrm{S}$, Nogueira C, Paranhos R ANd Villac MC. 1999b. Caractéristiques Hydrobiologiques de la Baie de Guanabara (Rio de Janeiro, Brésil). J Rech Oceanogr 24: 33-41.

VALENTIN JL, TENENBAUM DR, BONECKER ACT, BONECKER SLC, NogueIRA CR AND VIllaC MC. 1999a. O Sistema Planctônico da Baía de Guanabara: Síntese do Conhecimento. Oecol Brasil 7: 35-59.

VEGA-PÉREZ LA AND LiANG TH. 1992. Feeding of pelagic chaetognath, Sagitta friderici Ritter-Záhony off Ubatuba region (São Paulo, Brazil). Bolm Inst Oceanogr S Paulo 40: 93-100. 